International Journal of Linguistics, Literature and Translation

ISSN: 2617-0299 (Online); ISSN: 2708-0099 (Print)

DOI: $10.32996 /$ ijllt

Journal Homepage: www.al-kindipublisher.com/index.php/ijllt

\title{
Linguistic Analysis of Some Errors of Arabic-Turkish Writing: A Case Study of Arabic Learner in Dubai
}

\author{
Mohamed Moghazy 8 (D) \\ Graduate Student, University of Illinois, College of Education, Education Policy and Leadership Department, Urbana-Champaign, \\ USA \\ $\triangle$ Corresponding Author: Mohamed Moghazy, E-mail: moghazy_mohamed@yahoo.com
}

ARTICLE INFORMATION

Received: April 11, 2021

Accepted: May 23, 2021

Volume: 4

Issue: 5

DOI: $10.32996 /$ ijllt.2021.4.5.14

\section{KEYWORDS}

Writing, Arabic, Turkish, CBI, ACTFL

\section{ABSTRACT}

This research focuses on the phonetic distinctions between Arabic and Turkish and the student's work. Based on ACTFL writing competence requirements, the morphological and syntactical differences between Arabic and Turkish in writing an essay about the student's summer vacation. Also, what is the impact of L1 on L2 and L3 writing proficiency? Additionally, the phonological and morphological differences between Arabic and Turkish, and syntactical variations in Arabic and Turkish. Lastly, a grade 11 trilingual IB student is a case study of the research. Also, CBI (content-based instruction method) and different methods could help students enhance their writing proficiency.

\section{Introduction}

Learning how to share your ideas and experience with others by writing is a significant development field for the second language (L2) Arabic language learners. According to some research, writing is a primary language skill that L2 learners struggle with rather than saying, hearing, or reading (Bell \& Burnaby, 1984; Bialystok, 1978; Brown \& Yule, 1983; Nunan, 1989; White, 1981).

This research has traditionally focused on propositional data (i.e., the lexical, syntactic, and discoursal units found within a text Crossley, 2013; Crossley \& McNamara, 2012), such as lexical diversity, word repetition, text length, and word frequency (e.g., Connor, 1990; Engber, 1995; Ferris, 1994; Frase, Faletti, Grant, \& Ginther, 1999; Jarvis, 2002; Jarvis, Grant, Bikowski, \& Ferris, 2003; Reid, 1986; 1990; Reppen, 1994).

Furthermore, this study focused specifically on phonological differences between Arabic and Turkish and what the student has produced. The morphological differences and syntactical variations between Arabic and Turkish in writing an essay about the student's summer vacation based on ACTFL writing proficiency standards.

\subsection{L2 writing proficiency}

Writing in Arabic as a second language (L2) is a vital part of the Arabic language curriculum and Arabic language proficiency in daily life situations. Research into $\mathrm{L} 2$ writing has investigated a broad spectrum of variables that explain writing development and proficiency, including first language background (Connor, 1996), writing purpose, writing medium (Biesenbach-Lucas, Sigrun, \& Wesenforth, 2000), cultural expectations (Matsuda,1997).

The current study was focused on the simple assumption that linguistic error analysis in a text is closely linked to human expectations of writing capacity. It represents the writers' exposure to a second language and their knowledge and practice learning and communicating in that language (Crossley, 2013; Dunkelblau, 1990; Kamel, 1989; Kubota, 1998).

Additionally, unlike L1 writing, L2 writing has a wide range of linguistic development (e.g., syntax, morphology, and vocabulary) and is based on writing and language abilities (Weigle, 2013b). As a result, linguistic errors in a document are accurate indicators

\section{K C AL-KINDI CENTER \\ R D FOR RESEARCH AND DEVELOPMENT}

Your gateway to world-class research

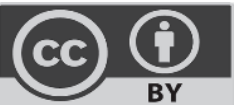

Published by Al-Kindi Center for Research and Development, London, United Kingdom. Copyright (c) the author(s). This open access article is distributed under a Creative Commons Attribution (CC-BY) 4.0 license 
of L2 writing proficiency (although not the only cues). Propositional errors in the text, such as lexical, syntactic, and discourse units, are familiar cues used in writing studies.

Researchers have used such clues to investigate L2 writing production and constraints using longitudinal approaches (Arnaud, 1992; Laufer, 1994), approaches that forecast essay output (Crossley \& McNamara, 2012; Ferris, 1994; Engber, 1995), and approaches that look at differences between L1 and L2 writers (Arnaud, 1992; Laufer, 1994). Also, methods that look at differences between L1 and L2 writers (Arnaud, 1992; Laufer, 1994 (Connor, 1984; Crossley \& McNamara, 2009; Reid, 1992; Grant \& Ginther, 2000), approaches that look at gaps in writing subjects (Carlman, 1986; Hinkel, 2002; Bonzo, 2008; Hinkel, 2009). Besides, approaches that look at everyday writing activities (Carlman, 1986; Hinkel, 2002; Bonzo, 2008; Hinkel, 2009) (Cumming et al., 2005, 2006; Guo, Crossley, \& McNamara, 2013; Reid, 1990).

Researchers have recently begun to look at situational cues (Zwaan, Magliano, \& Graesser, 1995) linked to the temporality, spatiality, or causality of a text (Crossley \& McNamara, 2009; 2012). Such research lays the groundwork for understanding writing proficiency, the linguistic growth of L2 authors, how L2 writers vary from L1 writers linguistically, and how prompt w prompt and task influence written production.

Higher rated L2 essays include more terms (Carlson, Bridgeman, Camp, \& Wanderers, 1985; Ferris, 1994; Frase et al., 1999; Reid, 1986; 1990; Reppen, 1994), use words with more letters or syllables (Frase et al., 1999; Grant \& Ginther, 2000; Reid, 1986, 1990; Reppen, 1994). Also, it displays greater lexical diversity (Engber, 1995, Grant \& Ginther, 2000; Jarvis, 2002; Reppen, 1994). More subordination (Grant \& Ginther, 2000) and instances of passive voice are found in L2 essays classified as higher quality (Ferris, 1994; Grant \& Ginther, 2000). Researchers have looked at direct relations and referential ties within a text from the perspective of cohesion.

These studies' results do not show the same degree of consensus as those that look at text's lexical and syntactic features. For example, previous research has found that more advanced L2 writers generate more connectives and pronouns (Jin, 2001; Reid, 1992). Furthermore, Higher-rated essays have fewer conditional connectives (e.g., if-then), fewer positive logical connectives (e.g., and, also, then), less subject word overlap, less provided knowledge, and less temporal cohesion (e.g., aspect repetition; Crossley \& McNamara, 2012; Guo et al., 2013). In general, the results suggest that lexical sophistication, syntactic ambiguity, and, to some extent, cohesion can be used to differentiate high proficiency L2 essays from low proficiency L2 essays.

\section{Methodology}

\subsection{Participant}

Hajar is a Turkish American student born in the United States and lived there for ten years. Also, she grows up as a multilingual learner with English, Turkish and Arabic. She is in the grade 11 I.B. program. She enrolled in the Arabic program at an international school in Dubai, U.A.E. She was raised in a religious family who taught her the Arabic language for a religious purpose that is reciting the Holy Qur'an. Her family moved to Dubai in 2009, and she speaks the Emirati Arabic dialect and reads it with diacritics such as in the Holy Qur'an.

Moreover, she could read, write, and speak English and Turkish properly. However, she learned English after she learned the Turkish language. She speaks Turkish at home, and all the family is practicing Turkish in daily life situations. She considers herself a Turkish girl with an American passport, even holding a Turkish passport. It is the language and the culture of the Turkish language that is affected by her sociocultural. Lastly, Turkish is her L1, English is her L2, and Arabic is her L3.

We will focus on the community of Dubai to see how is the environment helps our learner to develop her language or not? In Dubai, we have more than 75 nationalities, and many different languages are used in the United Arab Emirates. Members of all these nationalities have children, and they are studying in international schools in Dubai. Moreover, it is obligatory to learn the Arabic language because of the government's vision of providing opportunities for foreigners living in Dubai to learn Arabic. However, the students are facing a challenge in learning Arabic in these international schools (Moghazy, 2020).

Moreover, Arabs living in Dubai are not using modern standards of Arabic, but they are using language variety based on their nationalities. In other words, the code between the Arabic language learners and society is not valid because it is not the same (Wardhaugh \& Fuller, 2015). In Dubai society, there are five groups are living and using their language variety: 1) dialects of the Arabian Peninsula, 2) Mesopotamian dialects, 3) Syro-Lebanese dialects, 4) Egyptian dialects, and 5) Maghreb dialects. So, students are learning the modern standard Arabic at Dubai private schools, which is not the same dialect in the real-life. Hence, when trying to communicate or use the Arabic language in a real-life situation, they struggle because of the lack of Arabic dialects, as shown in figure 1. 


$\begin{array}{lll}\text { (8) } & \begin{array}{l}\text { pr 1sg } \\ \text { 'I' }\end{array} & \begin{array}{l}\text { v lsg imperf-ind } \\ \text { 'to like' }\end{array} \\ \text { MSA } & \text { Pana } & \text { Puhibbu } \\ \text { TCA } & \text { Pana } & n-h i b b \\ \text { ECA } & \text { Pana } & \text { ba-hibb } \\ \text { LCA } & \text { Pana } & \text { b-hibb } \\ \text { ICA } & \text { Pa:ni } & \text { hibb } \\ \text { SCA } & \text { Pana } & \text { hibb }\end{array}$

Bassiouney, (2009, p.23)

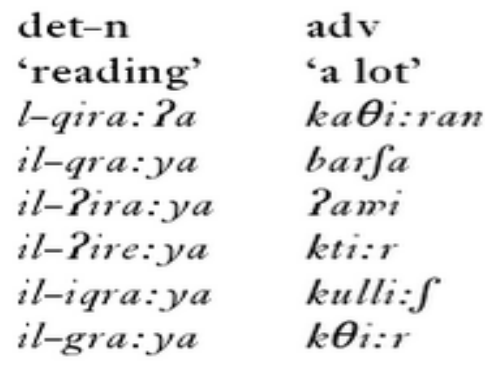

Figure 1 Arabic Dialect (Bassioney, 2009).

Additionally, Arabic language learners can hear a different way or language variety for the same question in Arabic. For example, how are you? In Gulf dialect is "shlonak شلونك "شو أخبارك "shoo akhbarak "شيفك in Syrian and Lebanese is "kefak and in Egyptian is "ezzayak إزيك." On the other side, the learners of Arabic in international schools in Dubai learned the meaning of, how are you? is "كيف الحال kayfa al hal" which is not the same as what they hear in Dubai society².

\section{Phonological and morphological differences between Arabic and Turkish}

The Turkish language has a single word to produce the meaning as a sentence in the Arabic language, and Turkish is an agglutinative term, meaning that morphemes are attached to a root word (Oflazer, 2018). For example, (evdeydiler.) (they were in the house.) (هم كانوا في البيت) if we compare between (evdeydiler) and (هم كانوا في البيت) we will find that the Turkish sentence accepts the inflections to add to the rood, but it is not acceptable in the Arabic sentence.

Fig. 1.2 Two examples of the cascaded operation of vowel harmony (Oflazer 2014) (Reprinted with permission)

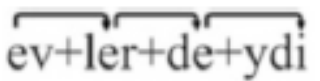

(they were in the houses)

\section{oku+yabil+iyor+du}

Figure 2 Two examples of the cascaded operation of vowel harmony (Oflazer, 2018)

As shown in figure 2, we could say that: (ev), which means home, (-ler) is plural, and it had been added to give the plural meaning. Also, (-de) gives the meaning of them being at home, and (-di) makes the verb in the past tense just like "were." As the following figure 3 shows, the root system in Arabic.

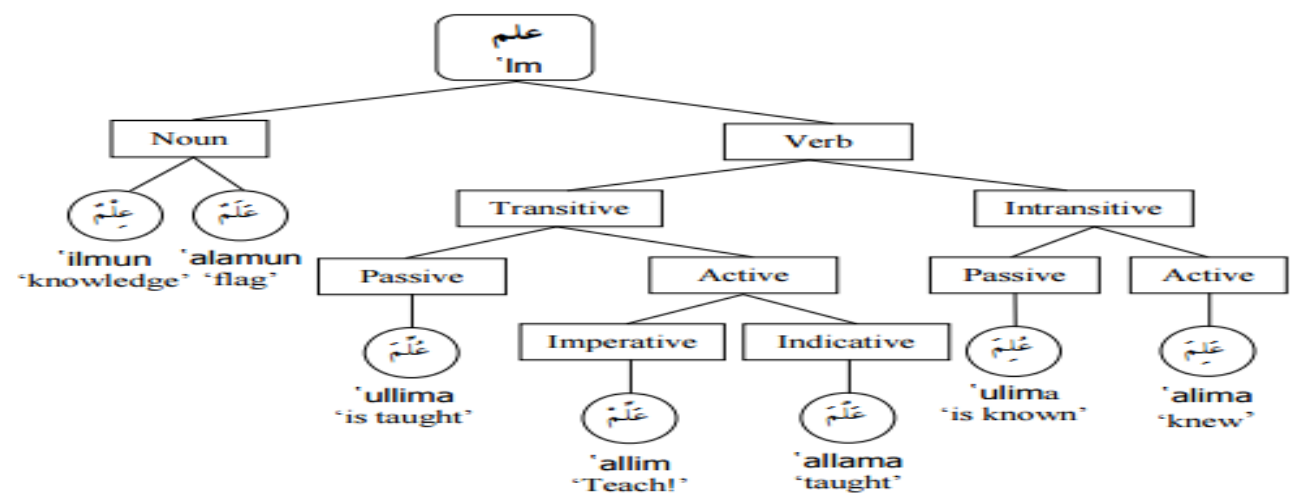

Figure 3 Arabic root (Abdul Jaleel, 1998)

\footnotetext{
${ }^{2}$ Varieties of Arabic spoken in Dubai include: Tunisian Colloquial Arabic (T.C.A.), part of the North African group of dialects; E.C.A., part of the Egyptian group of dialects; Lebanese Colloquial Arabic (L.C.A.), part of the Levantine group of dialects; Iraqi Colloquial Arabic (I.C.A.), part of the Mesopotamian Arabic group; and finally, Saudi Colloquial Arabic (S.C.A.), part of the Gulf Arabic dialect group.
} 
Another example, with a root of "Ka-Ta-B" "كتبب."

\begin{tabular}{|c|c|c|c|}
\hline $\begin{array}{l}\text { Root } \\
\text { "Ka-Ta-B" "كتب." }\end{array}$ & Derived from & Lexical type & Meaning \\
\hline & "Ka-Ta-Ba" "كتَب." & Verb & He wrote. \\
\hline & "Ya-K-TuB" "يْكْتُب." & Verb & He writes. \\
\hline & "Sa-Ya-K-TuB" "سَتِكْتُبْ." & Verb & He will write. \\
\hline & "Ki-Ta-B" "كِتَاب." & Noun & A book. \\
\hline
\end{tabular}

Figure 4 Arabic roots

Fig. 1.3 Derivations in a complex Turkish word (Oflazer 2014) (Reprinted with permission)

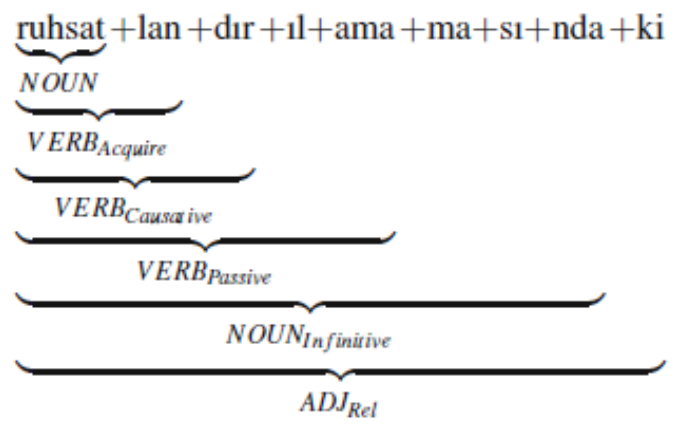

Figure 5 Derivations in a complex Turkish word (Oflazer, 2018)

As shown in figure 6, there are bound morpheme and free morpheme in the Arabic language.

\begin{tabular}{|l|l|l} 
Free morpheme & Bound morpheme & Zero morpheme \\
\hline Such as: "I am" "أنا.ل" & Such as: "the" & Hidden pronouns.
\end{tabular}

Figure 6 Arabic morphemes (Abdul Jaleel, 1998)

We need to analyze the following sentence to gain the meaning as in figure 7:

\begin{tabular}{|c|c|c|}
\hline bound morpheme, which refers to "she." & Present tense for "she." & ت \\
\hline Free morpheme & work & 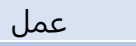 \\
\hline $\begin{array}{l}\text { It is not written, but it is hidden, and it is zero } \\
\text { morphemes. }\end{array}$ & she & هي \\
\hline Bound morpheme. & the & ال ال \\
\hline Free morpheme & doctor & طبيبة \\
\hline Free morphemes & In & في \\
\hline Bound morpheme. & the & ال ال \\
\hline Free morpheme. & hospital & مستشفى \\
\hline
\end{tabular}

Figure 7 Arabic sentence

Coming back to the morphonology of the Turkish language, we will find that it has eight vowels, and there are a lot of words and roots that were heavily loaned from Arabic, such as: (Kitab). For consonants, Turkish has 26 but in orthography using only 21

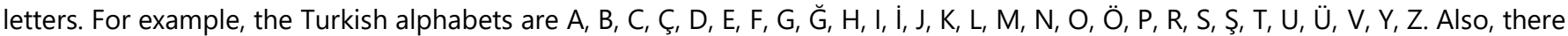
are eight vowels in the Turkish alphabet, which are $a, e, I, i, O, \ddot{o}, u, \ddot{u}$ and there are 21 consonants in the Turkish alphabet which are; $b, c, c ̧, d, f, g, \breve{g}, h, j, k, l, m, n, p, r, s, s, t, v, y, z$.

On the other side, the Arabic language contains 34 segmental phonemes, as in figure 8:

\begin{tabular}{|c|c|c|}
\hline Short Vowels & Three & Fat-ha $\left({ }^{-}\right)$Kasrah (_), and Damma ( \\
\hline Long vowels & Three & Alif Madd(,(أ Wow Madd(,(و and Yaa' Madd(ي). \\
\hline Semivowels & Two & Wow (و) and Yaa' (يوم) (يوم) (changing) such as ) \\
\hline consonants & Twenty-six & ب ت ث ج ح خ د ذ ر ز س ش ص ض ط ظع ع ف ق ك ل م ن هـ ي \\
\hline
\end{tabular}

Figure 8 Arabic phonemes (Abdul Jaleel, 1998) 


\section{Syntactical variations in Arabic and Turkish}

As shown in figure 9, the Arabic language has prefixes, infixes, and suffixes.

\begin{tabular}{|c|c|}
\hline prefixes & Such as present tense letters, for example (he plays) (يلعب) letter Yaa' is the prefixes. \\
\hline infixes & $\begin{array}{l}\text { Such as (taa' Al-Ifti'al), for example, (ادخر) it was (دخر) then we added (ترادر) and became (ادخر) and } \\
\text { (taa') was converted to (dal) and joined together and became) }\end{array}$ \\
\hline suffixes & Such as (Possessive pronouns), for example, (my pen) (قلمي) Yaa' it is the suffix in the end. \\
\hline
\end{tabular}

Figure 9 Arabic prefixes, infixes, and suffixes (Abdul Jaleel, 1998)

On the side, as shown in figure 10, suffixes in Turkish.

\begin{tabular}{|l|l|}
\hline -me, -ma & $\begin{array}{l}\text { Used in negative sentences - verb root +suffix +tense } \\
\text { (Biz İspanya'ya gitmedik) (We did not go to Spain) }\end{array}$ \\
\hline -mak, -mek & This suffix is added to give the verb action of doing just like -ing \\
\hline -de, $-\mathbf{d a}$ & This suffix is added to give the verb action of existing, occurring, or being present \\
\hline -se -sa & These suffixes are added to the verb root to give the (if) meaning \\
\hline
\end{tabular}

Figure 10 Turkish suffixes (Razfar, 2014)

Based on the world atlas of language structure (Razfar, 2014, p201), Arabic language syntax is the subject + verb + objective. For example, my mother is calling you which means:(أمي تتصل بك).(Re)

On the other side, the order of words in the Turkish language is different from in Arabic, such as the subject + objective + verb. Hence, if we would like to say the same sentence in Turkish (my mother is calling you), it will be (Annem seni arıyor).

\section{Linguistic errors analysis and translanguaging}

As shown in figure 11, the participant starts to write her essay about her summer holiday, in the beginning, she introduced herself, but she missed to write "years old" (my age is seventeen years old) (.(عاما The error was because of the lack of proficiency in writing because, in Turkish, she needs to add "years old" as well. "system of writing, on how words sound." (Razfar, 2014, p48) There is a similarity between the word "year or age" in Arabic and Turkish, but the writing system is different. Hence, she could be confused about how to pronounce and write. She can pronounce in Turkish, but she cannot correspond with Arabic pronunciation.

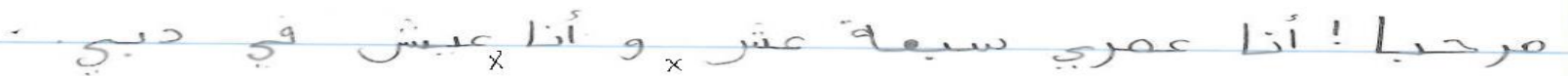

Figure 11 first and second errors

The second error was that: "I am living" "أنا عيش" she did not write the letter for the present tense as shown in figure 11. She just wrote the root of life "bound morphemes," meaning that they cannot exist unless they are attached to a root word (Azfar, 2014).

Also, Bound morphemes in Arabic such as present tense, hence, "live" "عاش" is the root with a vowel in the middle, when we will add the present tense for "I" we will add "I" at the beginning of the root with change the middle vowel letter to "ي" and it will be "' Same the morphemes in Turkish, but she could not write appropriately because in Arabic different from in Turkish as for each pronoun another morpheme in the present tense.

The third error is related to the syntax of the language as shown in figure 12, for example, she wrote" during the summer I went to turkey" "خلال الصيف ذهبت إلى تركيا" which in Arabic it is not in the correct order. As a sentence, she should write: "I went to Turkey during the summer" "ذهبت إلى تركيا خلال الصيف" based on the structure of the Arabic sentence. Moreover, in Turkish, the form is different from Arabic, despite the syntax will shed light on the inductive essence of learning and offer insights into how the mind functions (Razfar, 2014). Because she learned Turkish as the first language and always practicing at home, she writes an Arabic sentence with the same structure as Turkish.
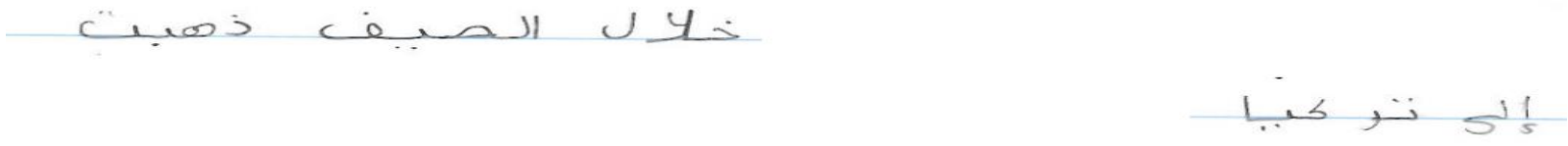

Figure 12 third error 

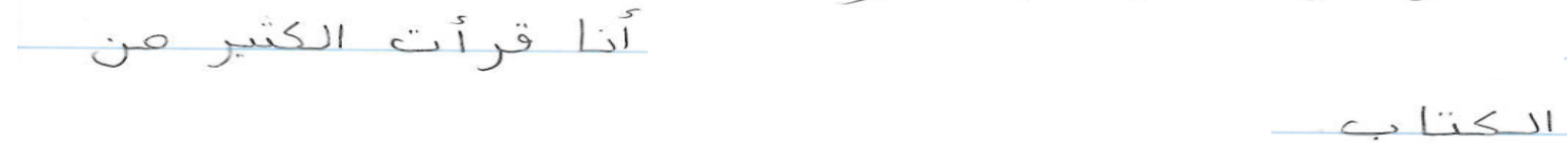

Figure 13 fourth error

The fourth error is related to numbers and counting when she wrote: "I read many books" "أنا قرأت الكثير من الكتاب and she wrote "many book" "الكثير من الكتاب" in a singular format as in Turkish and we begin by learning how to count numbers using words (Razfar, 2014). Also, she is still confusing between counting in Turkish and Arabic. In Turkish, the noun will be the same with all numbers, which means one book like ten books without modifying the noun. On the other side, In Arabic, the noun changes in counting; for example, one book is not the same as two books and not the same three to 10 books. We could find more explanation in figure 14 .

\begin{tabular}{|c|c|c|c|}
\hline One book & Two books & 3 to 10 books & 11 to infinity \\
\hline كتاب & كتابان & كتب & كتاب \\
\hline Noun as a singular & $\begin{array}{l}\text { The noun for two as } \\
\text { dual }\end{array}$ & $\begin{array}{l}\text { Number plus plural } \\
\text { of the noun }\end{array}$ & $\begin{array}{l}\text { A number plus the } \\
\text { singular of the noun }\end{array}$ \\
\hline
\end{tabular}

Figure 14 Arabic singular, dual, and plural

The fifth error is related to prepositions when she wrote: "video on YouTube." "فيديو يوتيوب" we can observe that she wrote then erased it as in Turkish the preposition connecting to the noun but in Arabic is separated. However, a preposition and a noun phrase make up an Arabic prepositional phrase (Razfar, 2014). So, in Arabic, it is two like English, "youtube" and "on." However, it is just one word in Turkish, including the root and on "youtube'da."

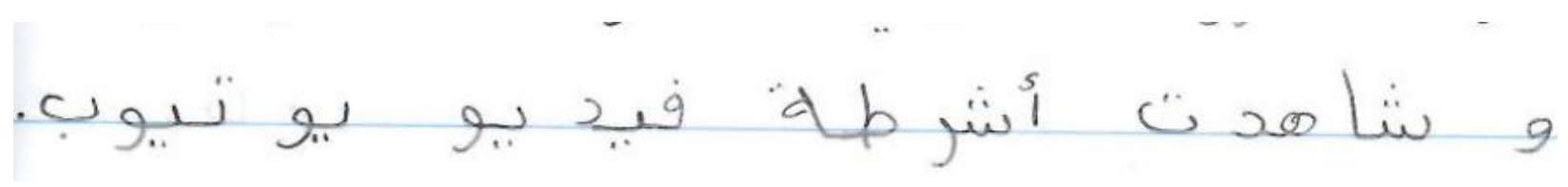

Figure 15 fifth error

Moreover, as shown in figure 16, another error is related to preposition when she wrote: "we went to" "ذهبنا" without "to" as in Turkish, went means "gitti" and we went "gittik." on the other side, Arabic like English in adding prepositions and she needs to add to "إl" to complete the meaning.

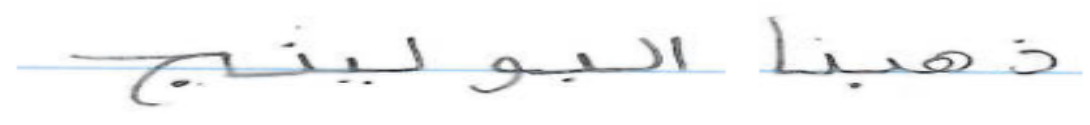

Figure 16 sixth error

The sixth error is related to the meaning of the words or lexical lack when she wrote: "I went to the top of the mountain." " زهبت but what she wrote in Arabic has a different meaning: "I went to raise the mountain.", which is other than what she meant. "lexical item "bus" is inflected for "number," (Razfar, 2014). Also, we stated the phrase of Razfar because in Arabic to raise, and high are same root (رفتع) (رتفع), so the learner could not distinguish between which one is suitable to use in the sentence to make sense for the meaning.

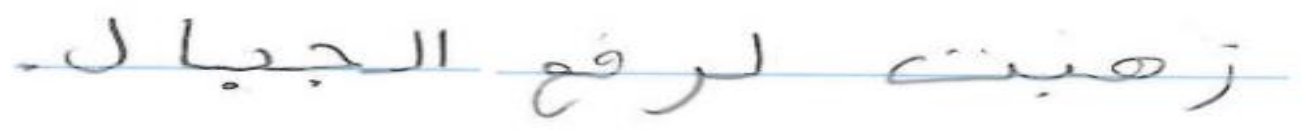

Figure 17 seventh error

\section{Discussion}

She could do better in writing tasks, but she did it in the class without any preparation. Usually, after vacation, students are not at their actual level because of the lack of practicing during the vacation. Occasionally, we assign writing tasks for students 
before going to the summer holiday to take notes and write down all the events they want to share with classmates and teachers when they will be back. Nevertheless, unfortunately, only a few students are doing the task as it is a formative assessment that is not graded.

Moreover, we could use different methods or approaches to develop students writing proficiency. For instance, the IB learners' profile and content-based instruction will be a suitable method to meet students' needs.

Furthermore, using C.B.I in writing tasks allows students to manage both content and language simultaneously. Also, we need to explain to students that the content is related to their own life, and they could use Arabic, Turkish, and English in the writing process, and they could rely on translation technology to develop their writing skills because students need to learn a lot of new words and phrases along the way (Razfar, 2014). Additionally, students cannot use a dictionary or another language translation apps in the writing process in the participant's school. They aim to "think in Arabic," which helps students gain proficiency in writing and to use the language.

Rapidly, when Razfar mentions the story of one Japanese professor who is writing the draft of all her academic work in her mother tongue (Japanese) first and then translating it to English (Razfar, 2014). Also, this method helps students to produce excellent and organized work.

Additionally, the teacher's role in C.B.I is to design clear objectives for content, language, and scaffolding. The teacher should help students understand authentic materials by visuals aids, repeating, and building on their knowledge. Also, C.B.I would motivate students because it is based on their needs if they chose content from what they like. However, students are not using their native language or first language in C.B.I, but they develop their language skills by integrating the language into context (Larsen-Freeman \& Anderson, 2011).

"Vocabulary development is an integral part of every language teacher's activities" (Razfar, 2014, p.184). Hence, the word wall is essential in all language classes, but still, students have a lack in practicing words in Arabic because of the different meaning for the same root, such as raise and top (رفع ومرتفع) as the participant wrote in the essay. Hence, Arabic teachers need to develop the Arabic vocabulary by applying free writing for 5 minutes at least in each lesson to improve students writing skills and vocabulary knowledge. Also, students can use their dictionary or first language in free writing to fully understand the meaning of the new words.

"Learners move in and out of novice/expert roles depending on their role within an activity" (Razfar, 2014, p.186). Mostly in writing activities, students are allocated individually based on their levels, but when it is group work, most students are not participating fully because of the lack of clear instructions or individual roles in the group. Usually, students depend on one student or two who are good at writing, and the rest of the group is waiting or acting they are working.

Furthermore, the research task is to write about the summer holiday; but we made a big poster about the same task for all students based on their levels. For instance, Hajar, our participant, was responsible for writing the holiday benefits, but the novice learners wrote about good places to visit during the summer holiday. Also, the novice learners could write a sentence such as "I will visit the water park," hence, when the novice learners share their work with advanced learners will learn from each other, and both writing skills will be developed from their own work and their peers' work as well.

Furthermore, high achievers always find different meanings or synonyms for the same word they already knew. Besides, Hajar said: "I did not know that there is a different word for the park than I knew" she knows (ملاهي) has the but she found that (حيقة) same meaning.

On the other side, teachers need to focus more on its methods to apply the C.B.I in the writing tasks. C.B.I has many techniques such as Dictogloss, Graphic Organizers, Language Experience Approach, Process Writing, and Dialogue Journals. For example, Dictogloss means students will listen twice to a short talk or reading on content. For the first time, students are listening only, and the second time, they will write two notes, and at the end, each student will rearrange the notes based on what they heard. Then, each student with a partner or a small group can work together to find out the best content closer to what they heard. Then they will share with a whole class for peer assessment.

Additionally, we could use a process writing approach; for example, the teacher will prepare authentic material for a young boy or a girl talking about his/her summer holiday in Arabic. After that, students will listen to it twice and, the third time, will take notes to help them write their task about the summer holiday. The starting point is reliable as they hear about the topic and build their notes.

Moreover, we could present the content as a reading text for those who prefer reading, and their starting point will be from taking notes but not copying sentences from the text but imitate ideas. However, the negative impact or influence of the reading 
approach is that most of the learners are not taking notes. Nevertheless, they are copying many sentences to connect them in different orders to write a paragraph, but the outcome is that the paragraph is not coherent, and they did not learn how to write about their life or enhance their writing skills.

\section{Conclusion}

Furthermore, we could help the Arabic learners to write in Arabic easier by using mind maps visual aids to make it closer to them, as most of the learners' mother tongue is different from the Arabic language writing system. Also, the participant is learning other subjects such as mathematics, science, and physics in English, and there is no opportunity to practice Turkish as an academic language such as Arabic; hence, we could integrate the two languages to raise her skills and proficiency in the same time.

Moreover, we negotiate and re-negotiate our sense of self concerning the wider social world every time we speak (Norton, 2010). The idea is to engage students to use the language with a native speaker outside of the school or, in other words, the school should be a real-life application of using the language as in society.

Additionally, the study could be done on more students and compare their writing errors to each other. Still, the study compares Arabic and Turkish, so there is only one Turkish student. Also, we could involve more Turkish students from different grade levels, but the writing proficiency will be different, which will have a negative impact on the comparing. I do recommend future researches to compare English as L1 and Arabic as L2.

Lastly, Arabic teachers need to enhance their language skills by modifying their own teaching methods and content materials that rely on students' levels but not on students' years of studying Arabic (Moghazy, 2020).

\section{References}

[1] Abdul Jaleel, A. Q. (1998). Morpho-Phonology [Transliterated title]. 3ilm-Assaraf-Assawti Edition. Amman, Jordan: Dar Al-Azminah.

[2] Arnaud, P. J. (1992). Objective lexical and grammatical characteristics of $L 2$ written compositions and the validity of separatecomponent tests. In P. J. Arnaud \& H. Bejoint (Eds.), Vocabulary and applied linguistics (pp. 133-145). London, England: Macmillan.

[3] Bassiouney, R. (2009). Arabic Sociolinguistics. Edinburgh, G.B.: Edinburgh University Press. Retrieved from http://www.ebrary.com.proxy2.cl.msu.edu

[4] Bell, J., \& Burnaby, B. (1984). A handbook for E.S.L. literacy. Toronto, Canada: Ontario Institute for Studies in Education/Hodder and Stoughton.

[5] Biesenbach-Lucas, S., \& Weasenforth, D. (2001). E-mail and word-processing in the E.S.L. classroom: How the medium affects the message. Language Learning and Technology, 5, 35-165.

[6] Bialystok, E. (1978). A theoretical model of second language learning. Language Learning, 28, 69-83.

[7] Bonzo, J. D. (2008). To assign a topic or not: Observing fluency and complexity in intermediate foreign language writing. Foreign Language Annals, 41(4), 722-735.

[8] Brown, G., \& Yule, B. (1983). Discourse analysis. Cambridge, England: Cambridge University Press.

[9] Carlman, N. (1986). Topic differences on writing tests: How much do they matter? English Quarterly, 19, 39-49.

[10] Connor, U. (1996). Contrastive rhetoric: Cross-cultural aspects of second-language writing. Cambridge, England: Cambridge University Press.

[11] Crossley, S. A., \& McNamara, D. S. (2012). Predicting second language writing proficiency: The role of cohesion, readability, and lexical difficulty. Journal of Research in Reading, 35, 115-135.

[12] Crossley, S. A. (2013). Advancing research in second language writing through computational tools and machine learning techniques: A research agenda. Language Teaching, 46(2), 256-271.

[13] Crossley, S. A., Cai, Z., \& McNamara, D. S. (2012). Syntagmatic, paradigmatic, and automatic n-gram approaches to assessing essay quality. In P. M. McCarthy \& G. M. Youngblood (Eds.), Proceedings of the 25th International Florida Artificial Intelligence Research Society (FLAIRS) Conference (pp. 214-219). Menlo Park, CA: The AAAI Press.

[14] Cumming, A., Kantor, R., Baba, K., Erdosy, U., Eouanzoui, K., \& James, M. (2005). Differences in written discourse in independent and integrated prototype tasks for next generation TOEFL. Assessing Writing, 10(1), 5-43.

[15] Dunkelblau, H. (1990). A contrastive study of the organizational structures and stylistic elements of Chinese and English expository writing by Chinese high school students. Dissertation Abstracts International, 51(4), 1143A.

[16] Engber, C. A. (1995). The relationship of lexical proficiency to the quality of E.S.L. compositions. Journal of Second Language Writing, 4(2), $139-155$.

[17] Ferris, D. R. (1994). Lexical and syntactic features of E.S.L. writing by students at different levels of L2 proficiency. TESOL Quarterly, 28(2), 414-420.

[18] Fellbaum, C. (1998). WordNet: an electronic lexical database. Cambridge, MA: M.I.T. Press.

[19] Frase, L., Faletti, J., Ginther, A., \& Grant, L. (1999). Computer analysis of the TOEFL test of written English. (TOEFL Research Report No. 64). Princeton, NJ: E.T.S.

[20] Guo, L. Crossley, S. A., \& McNamara, D. S. (2013). Predicting human judgments of essay quality in both integrated and independent second language writing samples: A comparison study. Writing Assessment, 18(3), 218-238.

[21] Hinkel, E. (2002). Second language writers' text. Mahwah, NJ: Lawrence Erlbaum Associates.

[22] Jarvis, S. (2002). Short texts, best-fitting curves and new measures of lexical diversity. Language Testing, 19(1), 57-84.

[23] Jarvis, S., Grant, L., Bikowski, D., \& Ferris, D. (2003). Exploring multiple profiles of highly rated learner compositions. Journal of Second Language Writing, 12(4), 377-403. 
[24] Kamel, G. W. (1989). Argumentative writing by Arab learners of English as a foreign and second language: An empirical investigation of contrastive rhetoric. Dissertation Abstracts International, A: The Humanities and Social Sciences, 677-A.

[25] Kubota, R. (1998). An investigation of L1-L2 transfer in writing among Japanese university students: Implications for contrastive rhetoric. Journal of Second Language Writing, 7, 69-100.

[26] Reid, J. (1986). Using the Writer's Workbench in composition teaching and testing. In C. Stansfield (Ed.), Technology and language testing (pp. 167-188). Alexandria, VA: TESOL.

[27] Reppen, R. (1994). A genre-based approach to content writing instruction. TESOL Journal, 4(2), 32-35.

[28] Larsen-Freeman, D., \& Anderson, M. (2011). Techniques \& principles in language teaching. Oxford: Oxford University Press.

[29] Laufer, B. (1994). The lexical profile of second language writing: Does it change over time? RELC Journal, 25(2), 21-33.

[30] Matsuda, P. K. (1997). Contrastive rhetoric in context: A dynamic model of L2 writing. Journal of Second Language Writing, 6(1), 45-60.

[31] Moghazy, M. (2020). Teaching and learning Arabic as a second language online: A case study of Dubai during COVID-19 pandemic. University of Illinois, Urbana-Champaign, USA. Retrieved from http://hdl.handle.net/2142/109372

[32] Norton, B. (2010). Sociolinguistics and language education. Hornberger, N. H., \& McKay, S. L. (Eds.), Language and Identity (pp. 349 - 369). Buffalo, NY: Multilingual Matters.

[33] Nunan, D. (1989). Designing tasks for the communicative classroom. Cambridge, England: Cambridge University Press.

[34] Oflazer, Kemal, Saraçlar, Murat. (Eds.) (2018) Turkish natural language processing. Cham, Switzerland: Springer.

[35] Wardhaugh, R., \& Fuller, J. M. (2015). An introduction to sociolinguistics. Malden, MA, U.S.A.: Wiley Blackwell.

[36] Weigle, S. (2013b). English as a second language writing and automated essay evaluation. In M. D. Shermis, J. Burstein, \& S. Apel (Eds.), Handbook of automated essay evaluation: Current applications and new directions (pp. 36-54). New York, NY: Routledge.

[37] White, R. (1981). Approaches to writing. Guidelines, 6, 1-11.

[38] Zwaan, R. A., Magliano, J. P., \& Graesser, A. C. (1995). Dimensions of situation model construction in narrative comprehension. Journal of Experimental Psychology: Learning, Memory, and Cognition, 21, 386-397.

\section{Appendix A}

Turkish words borrowed in Modern Arabic

\section{Words}

\begin{tabular}{|c|c|c|}
\hline Arabic & Turkish & Description \\
\hline كويري & Kobru & 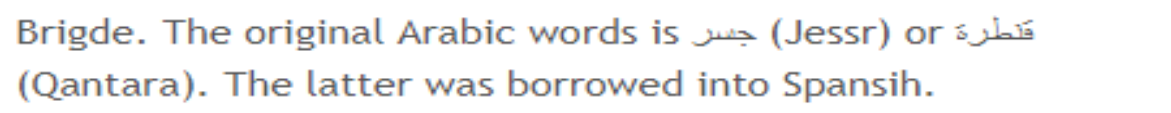 \\
\hline كات & Kat & $\begin{array}{l}\text { A story in a building. This word is used in the old part of } \\
\text { Alexandria, and is almost unique in Egypt. The correct Arabic } \\
\text { term is (Tabiq). }\end{array}$ \\
\hline أوضة & Oda & $\begin{array}{l}\text { Room. This is used in Egypt. The original Arabic is عرفة } \\
\text { (Ghorfa) }\end{array}$ \\
\hline أقفدم & Afandem & $\begin{array}{l}\text { Affirmative answer. Used when replying to a superior, } \\
\text { specially in the military. }\end{array}$ \\
\hline أيوة & Aywa & Affirmative answer. In everyday use. \\
\hline كمام & Tamam & Equivalent to "OK" \\
\hline 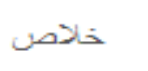 & Khalas & "Finished", "over", "done" \\
\hline و - ابور & Vapur & $\begin{array}{l}\text { The Turkish word seem to be derived from a European word } \\
\text { (Vapour), and refers to steam engines. Nowadays it is used } \\
\text { for ferry boats. In Arab countries, it is used for the steam } \\
\text { engine of a train. }\end{array}$ \\
\hline
\end{tabular}

Retrieved from: https://baheyeldin.com/linguistics/turkish-words-borrowed-in-modern-arabic.html 


\section{Appendix B}

Students' work sample

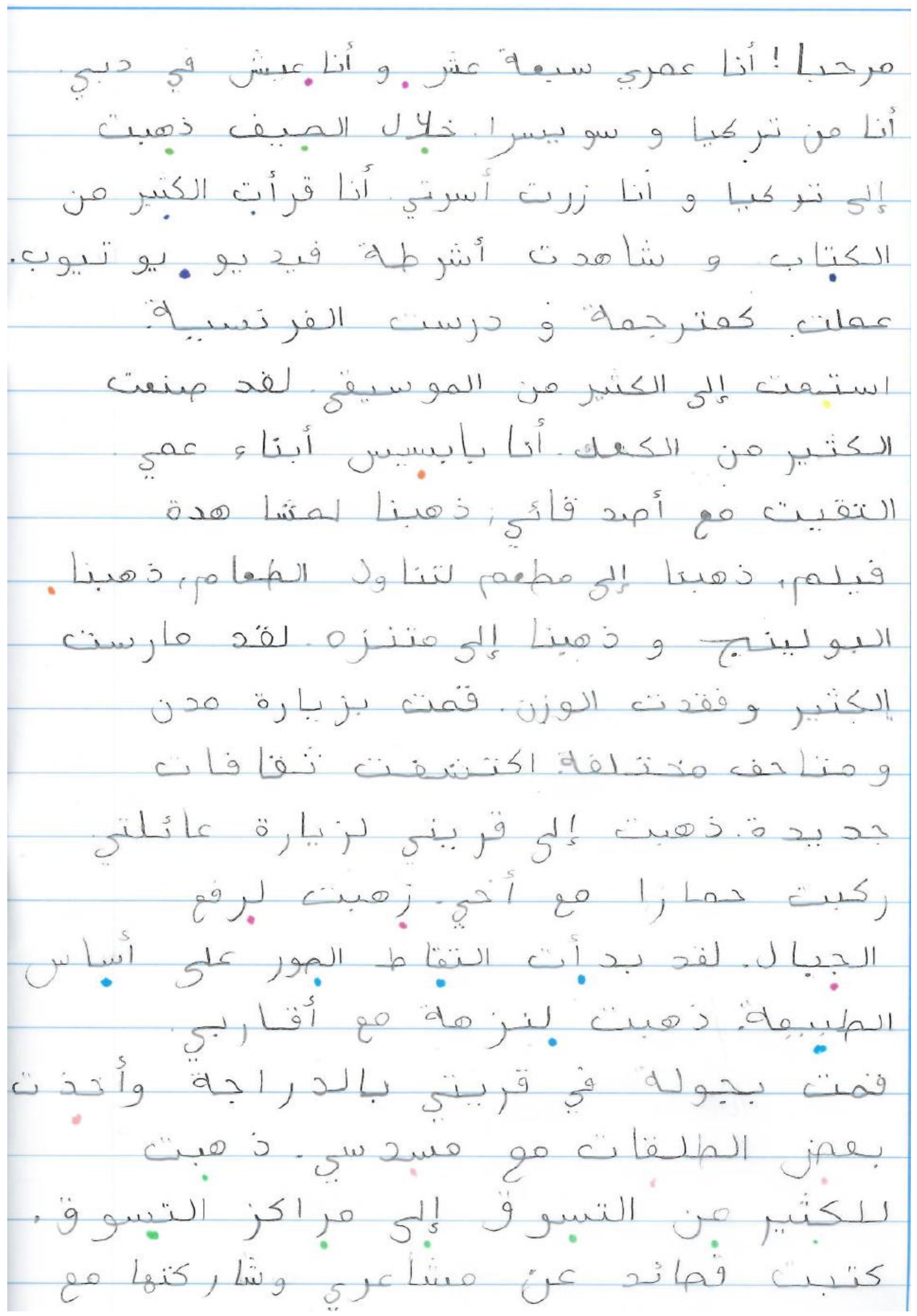

